\title{
Edutainment dalam Mata Pelajaran Pendidikan Agama Islam
}

\author{
Andrioza \\ SMP Muhammadiyah 13 Wonosegoro \\ andrioza@gmail.com \\ Badrus Zaman \\ IAIN Surakarta \\ badruszaman43@yahoo.com \\ DOI: 10.18326/mudarrisa.v8i1.117-144
}

\begin{abstract}
Abstrak
Tujuan penelitian ini adalah untuk mengetahui strategi dan hambatan edutainment pada mata pelajaran PAI di SMP Muhammadiyah 13 Wonosegoro tahun 2014, serta bagaimana mengatasi hambatan strategi pembelajaran edutainment pada mata pelajaran Pendidikan Agama Islam di SMP Muhammadiyah 13 Wonosegoro tahun 2014. Penelitian dilakukan melalui pendeskripsian fenomena-fenomena yang ada di SMP Muhammadiyah 13 Wonosegoro, dengan kehadiran peneliti sebagai pengamat dan sebagai pengumpul data. Data diperoleh dengan cara wawancara, observasi, dan dokumentasi. Strategi pembelajaran disusun untuk mencapai tujuan tertentu yang ditetapkan oleh guru. Suasana belajar yang menyenangkan dapat dirasakan oleh peserta didik dalam mencapai prestasi belajar, strategi pembelajaran edutainment diharapkan dapat mencetak lulusan yang tidak hanya dalam nilai (angka) yang baik, namun memiliki kecerdasan kognitif, emosional, dan kecerdasan spiritual. Pendekatan edutainment melalui permainan (game), humor, bermain peran (role play), demonstrasi dan cara-cara lain yang dapat dikuasai oleh guru dan siswa. Hambatannya, sumber daya manusia dalam menjalankan strategi pembelajaran edutainment, peserta didik cenderung
\end{abstract}


bermain hingga melupakan esensi pembelajaran, bahan pembelajaran, waktu pembelajaran yang minim, sarana dan prasana yang terbatas, lingkungan belajar yang kurang mendukung dalam penerapan strategi pembelajaran edutainment.

The purpose of the research is to determine the strategies and the barriers of edutainment learning strategy on Islamic religious lesson (PAI) in SMP Muhammadiyah 13 Wonosegoro 2014 also the ways to overcome barriers for the learning strategy. The research conducted through describing the phenomena that exist in SMP Muhammadiyah 13 Wonosegoro. The researcher acted as an observer and data collector. The data collected by interviews, of observations, documentation. The result shows that learning strategies are designed to achieve certain goals set by the teacher. Enjoyable learning atmosphere can be felt by learners in achieving learning. Edutainment learning strategy is expected to produce qualified people, who not only good in their score, but also has a cognitive, emotional and spiritual intelligence as well. Edutainment learning strategy applied through game, humor, role play, demonstrations and other ways that can be mastered by teachers and students. The obstacles are human resources as the doer of Edutainment Learning Strategy, learners tend to play and forget the essence of learning, materials, time limitation, limited facilities and infrastructures, also less supportive learning environment in the application of learning strategies edutainment.

Kata kunci: strategi pembelajaran, edutainment, PAI

\section{Pendahuluan}

Proses pendidikan dari masa ke masa terus melakukan inovasi, sesuai dengan perkembangan dan kemampuan manusia itu sendiri, sehingga pendidikan mengalami kemajuan yang cukup pesat. Hal ini terbukti dengan adanya penemuan-penemuan ilmu pengetahuan baru, yang sekaligus menunjukkan bahwa pendidikan selalu bersifat maju dan berorientasi ke depan. Perkembangannya trend dunia pendidikan abad 
ke-21 lebih berorientasi pada pengembangan potensi manusia, dan tidak lagi memusatkan pada kemampuan teknik dalam melakukan eksplorasi dan eksploitasi alam sebagaimana abad ke-20. Pergeseran ini didorong tidak hanya oleh kenyataan terjadinya krisis ekologi, tetapi juga oleh hasil riset terutama dalam bidang neuropsikologi (Hamruni, 2009:1).

Mengenai potensi manusia, khususnya potensi otaknya, hasil penelitian neuropsikologi dari Markowitz dan Jensen (2002:249) menunjukkan bahwa potensi manusia yang sudah teraktualisasikan masih sangat sedikit, baru sekitar $10 \%$. Penelitian tentang otak menunjukkan bahwa otak manusia paling sedikit terdiri dari 1 trilyun sel otak, termasuk 100 milyar sel saraf aktif (neuron) dan 900 milyar sel lain yang merekatkan, memelihara, dan menyelubungi neuron. Setiap satu dari 100 milyar neuron tersebut dapat tumbuh bercabang hingga sebanyak 20.000 cabang (dendrit). Cabang yang seperti sebuah pohon ini berfungsi menyimpan informasi. Kehebatan lain, sel otak aktif mampu membentuk koneksi (sinapsis) dengan kecepatan yang luar biasa, 3 milyar per detik. Koneksi tersebut adalah kunci kekuatan otak. Setiap menit, sel-sel aktif itu mampu menciptakan sambungan baru tidak kurang 100 ribu jalur. Jadi, otak manusia adalah computer yang super canggih, bahkan beribu kali lebih hebat dari pada computer tercanggih manapun di dunia. Potensi yang demikian besar, semua orang punya kemungkinan untuk menjadi cerdas, sukses dan berprestasi tinggal bagaimana proses pembelajaran mengaktualisasikannya.

Menurut Effendi (2005:24) dalam Pendidikan Agama Islam (PAI), penerapan konsep pembelajaran konvensional yang telah 
berlangsung selama ini cenderung tidak menghargai harkat anak didik sebagai manusia seutuhnya. Proses belajar-mengajar lebih menekankan pada kinerja jasmaniah dan mengabaikan kinerja batiniah. Padahal, seperti yang sudah dijelaskan al-Qur'an dalam penciptaan manusia, setiap orang (termasuk anak didik) tidak hanya terdiri dari tubuh fisik, tetapi juga psikis. Manusia terdiri dari jasmani dan rohani, lahiriyah dan batiniyah. Hal-hal yang bersifat batiniyah sendiri terdiri dari berbagai komponen, antara lain pikiran, ingatan, perasaan, dan kesadaran. Agar proses pembelajaran bisa berhasil dengan maksimal, seorang guru hendaknya mangakomodasi kedua aspek ini, yaitu aspek lahiriyah (badan) dan aspek batiniyah (pikiran, ingatan, perasaan, dan kesadaran).

Proses pembelajaran di kelas, sering kali siswa hanya dianggap sebagai wadah kosong yang harus dan dapat diisi dengan berbagai ilmu pengetahuan atau informasi apapun yang dikehendaki oleh pengajar (guru). Jarang ditemukan pengajar yang benar-benar memperhatikan aspek perasaan atau emosi siswa, serta kesiapan mereka untuk belajar, baik secara fisik maupun psikis. Acapkali terjadi, bila guru sudah masuk ke kelas kemudian siswa diarahkan untuk duduk tenang dan diam, lalu guru langsung mengajar. Diyakini, pada saat guru mata pelajaran, maka siswa pun akan belajar. Paradigma positivistik yang telah merasuki dunia pendidikan, termasuk PAI yang terjadi di SMP Muhammadiyah 13 Wonosegoro, sering kali membuat suasana pembelajaran menjadi kaku dan menegangkan. Betapa tidak, demi untuk mengejar target kurikulum misalnya, banyak guru yang secara sadar atau tidak, telah membebani siswa dengan berbagai materi pembelajaran. Guru memaksa siswa itu 
untuk mempelajari setumpuk bahan pembelajaran yang sudah dituangkan dalam silabus (kurikulum), tanpa peduli apakah siswa itu tertarik atau tidak, apakah materi itu bermanfaat bagi masa depan atau justru sebaliknya.

Pembelajaran mata pelajaran PAI yang berlangsung dan dilakukan dengan pendekatan yang bersifat memaksa ini menciptakan suasana pembelajaran yang tidak nyaman, menimbulkan rasa takut, dan bahkan bisa membuat stres. Kondisi yang tidak kondusif sangatlah tidak mendukung tercapainya proses dan hasil belajar yang optimal, bahkan sebaliknya bisa menggagalkannya. Belajar tidak pernah akan berhasil dalam arti yang sesungguhnya bila dilakukan dalam suasana yang menakutkan, belajar hanya akan efektif bila suasana hati siswa berada dalam kondisi yang menyenangkan. Terobosan dalam edutainment sebagai harmonisasi pembelajaran yang membuat kondisi kelas dan suasana pembelajaran yang berbeda, konsep yang ditawarkan pembelajaran edutainment sangat menarik dan sesuai dengan PP No. 19 tahun 2005 tentang standar nasional pendidikan pasal 19 ayat 1 yang berbunyi: Standar nasional pendidikan adalah kriteria minimal tentang sistem pendidikan di seluruh wilayah hukum Negara Kesatuan Republik Indonesia.

Berdasarkan observarsi awal proses pembelajaran PAI di SMP 13 Muhammadiyah Wonosegoro dengan mewawancarai beberapa siswa, kesan yang mendalam pada siswa adalah entertaiment (hiburannya) lebih mendominasi pada kegiatan belajar mengajar, esensi penggunaan edutainment adalah penguasaan materi pembelajaran. Hambatan dalam 
pelaksanaan edutainment sangat bervariasi, antara lain: guru kurang memahami konsep edutainment; respon peserta didik terhadap pelajaran tidak fokus (anak cenderung bermain); bahan pembelajar yang tidak memadai; waktu yang sangat minim; alat peraga yang terbatas; situasi dan lingkungan yang tidak mendukung (hasil wawancara dengan guru dan kepala sekolah).

Menurut Hamruni (2009:15) konsep dasar edutainment berupaya agar pembelajaran yang terjadi berlangsung dalam suasana yang kondusif dan menyenangkan. Ada tiga asumsi yang menjadi landasannya, yaitu: asumsi pertama; perasaan positif (senang/gembira) akan mempercepat pembelajaran, sedangkan perasaan negatif, seperti sedih, takut, terancam dan merasa tidak mampu, akan memperlambat belajar atau bahkan bisa menghentikannya sama sekali. Upaya menciptakan kondisi ini, maka konsep edutainment mencoba memadukan dua aktivitas yang tadinya terpisah dan tidak terhubung, yakni "Pendidikan"dan "Hiburan". Asumsi kedua; jika seseorang mampu menggunakan potensi nalar dan emosinya secara jitu, maka akan membuat loncatan prestasi belajar yang tidak terduga sebelumnya. Menggunakan metode yang tepat, siswa dapat meraih prestasi belajar secara berlipat ganda, hal ini merupakan peluang dan sekaligus tantangan yang menggembirakan bagi kalangan pendidik.

Teori-teori belajar yang berupaya mengembangkan kemampuan belajar, sehingga membuat lompatasn-lompatan prestasi inilah yang kemudian dikenal dengan teori-teori belajar era Quantum. Pada intinya, tujuan dari berbagai teori pembelajaran ini sama, yaitu bagaimana membuat proses pembelajaran menjadi efektif dan menyenangkan. 
Asumsi ketiga; apabila setiap siswa dapat dimotivasi dengan tepat dan diajar dengan cara yang benar, cara yang menghargai gaya belajar dan modalitas peserta didik, maka semua siswa akan dapat mencapai hasil belajar yang optimal. Pendekatan yang digunakan adalah membantu siswa untuk dapat mengerti kekuatan dan kelebihannya, sesuai dengan gaya belajar masing-masing. Siswa akan diperkenalkan dengan cara dan proses belajar yang benar, sehingga akan belajar secara benar, sesuai dengan gaya masing-masing. Upaya menerapkan ketiga asumsi tersebut, konsep edutainment menawarkan suatu sistem pembelajaran yang dirancang dengan satu jalinan yang meliputi siswa, pendidik (guru), proses pembelajaran (metode) dan lingkungan pembelajaran. Konsep edutainment menempatkan siswa sebagai pusat dari proses pembelajaran, dan sekaligus sebagai subjek pendidikan.

Berangkat dari latar belakang permasalahan di atas, maka penulis tertarik untuk mengadakan penelitian dengan judul "Strategi Pembelajaran Edutainment pada Mata Pelajaran PAI di SMP Muhammadiyah 13 Wonosegoro". Dengan permasalahan bagaimana strategi pembelajaran edutainment pada mata pelajaran Pendidikan Agama Islam di SMP Muhammadiyah 13 Wonosegoro, bagaimana hambatan pelaksanaan strategi pembelajaran edutainment pada mata pelajaran Pendidikan Agama Islam di SMP Muhammadiyah 13 Wonosegoro, dan bagaimana mengatasi hambatan strategi pembelajaran edutainment pada mata pelajaran Pendidikan Agama Islam di SMP Muhammadiyah 13 Wonosegoro. 


\section{Metode Penelitian}

Penelitian ini merupakan penelitian lapangan (field research) pengambilan data-data yang terkumpul dari lapangan secara langsung. Jenis penelitian ini adalah penelitian kualitatif dengan pendekatan deskriptif, yaitu data yang terkumpul dijelaskan dengan kata-kata, atau kalimat, gambar dan bukan dengan angka (Moleong, 2010:4). Penelitian ini peneliti akan mendeskripsikan fenomena-fenomena yang terjadi di SMP Muhammadiyah 13 Wonosegoro yang terkait dengan strategi pembelajaran Edutainment pada mata pelajaran Pendidikan Agama Islam.

\section{Strategi Edutainment Mata Pelajaran PAI}

Strategi Edutainment mata pelajaran PAI di SMP Muhammadiyah 13 Wonosegoro. Berdasarkan hasil pengamatan, wawancara dan proses penelitian secara keseluruhan dilapangan. Penulis dapat menyimpulkan tentang strategi pembelajaran yang digunakan oleh lembaga pendidikan SMP Muhammadiyah 13 Wonosegoro, yang berkaitan dengan mata pelajaran Pendidikan Agama Islam terbagi dalam proses pembelajaran serumpun yaitu ibadah (fikih), tarih (sejarah Islam), akidah ahlak dan alQur'an. Strategi merupakan modal utama bagi guru yang ingin mencapai nilai-nilai/esensi pembelajaran. Guru adalah panutan bagi muridmuridnya, seorang guru harus mencerminkan sifat, prilaku, budi pekerti yang baik, nantinya akan ditiru, baik itu guru sekolah (SD, SMP, SMA, atupun Dosen). Menjadi guru adalah pilihan, niat mulia seorang guru berdasarkan perjuangan yang mempunyai makna bukan semata-mata 
mencari kebutuhan ekonomi melainkan mengamalkan sebuah ilmu yang dimiliki guna mencetak kader-kader bangsa supaya memiliki sumber daya manusia yang mapan dalam segala hal kecerdasan, baik itu potensi dan bakat dapat dikembangkan dalam dunia pendidikan yang formal maupun non formal.

\section{Strategi Pembelajaran di SMP Muhammadiyah 13 Wonosegoro}

Kepala Sekolah SMP Muhammadiyah 13 Wonosegoro menyampaikan dalam wawancara bahwa strategi pembelajaran sangat penting, karena dengan mempersiapkan strategi pembelajaran akan mengetahui perkembangan belajar anak didik, dengan begitu guru pun akan mudah dalam menyampaikan tujuan matapelajaran yang akan dicapai. Secara tidak langsung apa yang dikemukakan oleh bapak MLK merupakan sebuah acuan bagi guru-guru PAI yang dalam proses penerapan strategi pembelajaran. Guru harus memiliki jiwa seni, tidak hanya begitu-begitu saja (monoton), jadi guru gampang-gampang susah, karena seorang guru akan mempertanggung jawabkan pekerjaannya baik di dunia maupun akhirat. Menjadi guru tidak hanya sekedar mampu mengajarkan mata pelajaran dengan baik, namun juga harus memahami psikologi peserta didik. Siswa membutuhkan lebih dari sekedar pelajaran yang masuk dalam kurikulum, membutuhkan motivasi, inovasi, karakterisasi, dan visi yang jelas dalam hidupnya. Maka dari itu, menjadi seorang guru haruslah memiliki seni dalam mentransfer ilmu kepada anak didik. Seni yang mampu meramu kurikulum yang kaku menjadi kurikulum yang mempunyai kekuatan penuh dalam pendidikan (Kadarsih, 2012:5). 
Sesuai dengan pendapat bapak SY yang mana tujuan yang akan dicapai anak tidak bosan dalam menjalani kegiatan pembelajaran dengan berbagai proses baik itu dengan metode, teknik, dan taktik yang berbedabeda mempunyai tujuan yang jelas yang dapat diukur keberhasilannya, sebab tujuan adalah hal penting dalam implementasi suatu strategi. Maka yang perlu diperhatikan yaitu strategi pembelajaran adalah merupakan hal yang pokok dalam kegiatan pembelajaran ada dua hal yang harus dicermati dari strategi. Pertama; strategi pembelajaran merupakan rencana tindakan (rangkaian kegiatan) termasuk pengguna metode dan pemanfaatan berbagai sumber daya dalam pembelajaran. Penyusunan suatu strategi ini baru sampai pada proses penyusunan rencana kerja belum sampai pada tindakan. Kedua; strategi disusun untuk mencapai tujuan tertentu. Artinya, arah dari semua keputusan untuk mencapai tujuan. Dengan demikian, penyusunan langkah-langkah pembelajaran, pemanfaatan berbagai fasilitas dan sumber belajar semuanya diarahkan dalam upaya pencapain tujuan (Hamruni, 2011:3).

\section{Strategi Pembelajaran Edutainment dalam Mata Pelajaran PAI}

Mata pelajaran Pendidikan Agama Islam sarat dengan nilai-nilai spiritual dan kemanusiaan yang sangat dibutuhkan oleh peserta didik. Materi yang direncanakan memerlukan implementasi melalui pembiasaan sehingga dapat dikuasai oleh peserta didik dengan suasanya yang menyenangkan. Kepala Sekolah selalu memantau proses ini dan menghimbau kepada guru untuk melakukan inovasi secara terus menerus untuk mencapai tujuan pembelajaran. Kepala sekolah mencoba untuk mengadopsi 
edutainment sebagai strategi pembelajaran bagi pendidikan agama Islam. Hal ini sebagaimana diungkapkan pada wawancara dengan peneliti.

Kepala sekolah (MLK) selalu memberikan motivasi kepada guru agama yang menjadi garda terdepan untuk meningkatkan iman dan taqwa anak didik di SMP Muhammadiyah 13 Wonosegoro, kemerosotan nilainilai Islam dalam kehidupan menjadi dasar MLK memantau perkembangan anak didik dan guru dalam menerapkan konsep pembelajaran yang kiranya dibutuhkan anak saat ini, dengan menggunakan metode pembiasaan yang dilakukan setiap jam pertama anak melaksanakan tadarus yaitu membaca juz ama, dan dicatat dalam buku prestasi anak, lalu guru menandatanganinya, kegiatan rutin pagi guru selalu kumpul dulu dikantor sebelum berangkat ke kelas, saya ajak berdoa bersama dan apabila saya tidak bisa hadir lebih awal atau dapat tugas keluar secara otomatis wakil saya yang memimpin, dan saya ingatkan selalu, kondisi ruangan kelas harus selalu diperhatikan baik kebersihan, tata ruangan, kedisiplinan dan kerapihan siswa jadi setelah itu baru dilanjutkan dengan membaca doa dan dilanjutkan tadarus, perintah ini selalu saya tekankan kepada guru yang masuk jam pertama, strategi ini saya adopsi ya dari edutainment juga mas, karna dengan begitu saya dapat memberikan yang terbaik buat guru dan sesuai dengan visi misi sekolah. Yaitu mencetak lulusan yang tidak hanya dalam nilai (angka) yang baik, namun harus memiliki kecerdasan kognitif, emosional, dan kecerdasan spiritual, maka dalam pembelajaran kesehariannya sudah fokus dalam peningkatan ibadah praktis. 
Hal yang baru bagi guru dan peserta didik di SMP Muhammadiyah 13 Wonosegoro dalam penerapannya, terkait dengan ini peneliti mengutip hasil wawancara dengan bapak MLK, bapak SY, dan bapak ES mengemukakan apa yang diketahui tentang edutainment, yaitu:

"Strategi pembelajaran edutainment edukasi dan entertainment pendidikan yang menghibur. Sistem pembelajaran yang menarik yang memadukan hiburan dan pembelajaran dalam penerapannya. Peserta didik senang nyaman dan menyenangkan, peserta didik tidak bosan dan senang dalam kegiatan pembelajaran baik guru yang menjelaskan ataupun teman sebaya. guru juga merasa senang dalam mengajar."

Apa yang diketahui oleh guru-guru PAI tetang edutainment merupakan strategi yang diterapkan dalam pembelajaran dan menjalankan proses pembelajaran. Artinya sumber daya manusianya sudah siap menjalankan strategi edutaiment baik dari pendidik dan peserta didik.

Beberapa ahli menjelaskan terhadap strategi pembelajaran edutainment, diketahui bahwa strategi pembelajaran edutainment merupakan konsep yang sangat menarik yang apabila dikembangkan dengan sistematis dan terstruktur akan memberikan sesuatu hal yang bermanfaat bagi dunia pendidikan, karena inti dari proses pendidikan di kelas adalah bagaimana para siswa bisa bersemangat, antusias, dan berbahagia dalam mengikuti pelajaran di kelas, karena edutainment merupakan sebuah konsep yang mana tujuannya adalah suatu proses pembelajaran yang didesain sedemikian rupa, sehingga muatan pendidikan dan hiburan bisa dikombinasikan secara harmonis untuk menciptakan pembelajaran yang menyenangkan. Menurut Sutrisno 
(2005:31-32) dalam hal ini pembelajaran yang menyenangkan biasanya dilakukan dengan humor, permainan (game), bermain peran (role play), dan demonstrasi. Pembelajaran juga dapat dilakukan dengan cara-cara lain, asalkan siswa dapat menjalani proses pembelajaran dengan senang. Karena strategi edutainment lebih menekankan cara pendidik dalam menjalankan fungsinya, maka hal ini tentu bukan pekerjaan gampang, sebab perubahan pola pengajaran dari konvensional, di mana peran kepala sekolah sebagai pengontrol dan penanggung jawab, jadi guru yang dominan di kelas.

karena edutainment merupakan proses pembelajaran dari kumpulan beberapa teori Humanizing The Classroom, Active Learning, The Accelerated Learning, Quantum Learning, Cooperatif Learning, menciptakan strategi edutainment hal yang mudah akan tetapi susah untuk di terapkan, oleh karena itu pelaksanaan pembelajaran edutainment ini membutuhkan ketekunan dan kesabaran yang tinggi, sehinggah paradigma ataupun asumsi yang cenderung berkembang selama ini dapat diubah secara perlahan (Hamid, 2013:15).

\section{Penerapan Strategi Edutainment dalam Mata Pelajaran PAI}

Pendidik memiliki pedoman yang harus dikuasai dari upaya dalam perencanaan dan menerapkan strategi edutainment dalam mata pelajaran Pendidikan Agama Islam. Bagaimana langkah-langkah yang dilakukan untuk SMP Muhammadiyah 13 Wonosegoro dalam menjalankannya hingga saat ini, melalui hasil wawancara dengan bapak MLK, peneliti 
dapat menggali hal-hal yang menjadi nilai-nilai pembiasaan yang telah diterapkan.

"Secara akademis target tahunan yang ingin dicapai, yaitu out put nya dalam penerapan edutainment pada matapelajaran al-qur"an targetnya yaitu hafal juz 30, dengan ditompangi pembiasaan tiap harinya setelah berdoa sebelum memulai pelajaran, dilanjutkan membaca juz ama, jadi setiap pagi anak-anak sudah terbiasa dalam melafadkan juz ama sehingga hafalannya akan terjaga. Memberikan kebiasaan pada anak didik dan tanggung jawab kepada mereka dengan membawa buku prestasi anak yang akan ditanda tangani oleh guru yang mengisi jam pelajaran pertama. memberikan waktu sholat dhuha kepada anak didik di waktu jam istirahat jadi memberikan jadwal dulu perkelas dalam pelaksanaan dan mengikuti jamaah sholat dzuhur dan sholat jum'at di sekolahan."

\section{Belajar Mudah dan Menyenangkan PAI}

Surat al-Baqorah ayat 185 yang telah dijelaskan di dalamnya mengandung makna bahwa Allah menghendaki kemudahan bagimu, dan tidak menghendaki kesukaran bagimu. sejalan dengan ayat ini bahwa seorang pendidik selayaknya memberikan kemudahan dalam pembelajaran dan memberikan kenyamanan dalam kegiatan belajar mengajar, sehingga peserta didik dapat menikmati dan dengan mudah menerima ilmu yang ditransformasikan, sehinggah menciptakan suasana keakraban yang dapat memaksimalkan hasil yang diproleh dalam proses belajar.

Teori memanusiakan ruang kelas (humanizing the classroom) pendidik hendaknya memperlakukan peserta didik sesuai dengan kondisi dan karakteristik masing-masing dalam proses pembelajaran. Tentunya dengan memahami kondisi dan karakteristik anak, guru ingin 
membangun iklim komunikasi yang baik dengan siswanya, agar para siswa mengerti apa yang disampaikan, dan membuat aktivitas belajar lebih menyenangkan. Menciptakan suasana yang nyaman dan menyenangkan, dituntut menjadi guru teladan dan cekatan merespons kebutuhan siswa, siap untuk berdiskusi, dan menjadi pendengar yang baik atas persoalan belajar siswa, yang lebih penting adalah memberikan aturan main yang jelas dan umpan balik terhadap siswa (Kadarsih, 2012:80).

\section{Menciptakan Lingkungan Belajar yang Kondusif}

Penerapan pembelajaran pada bapak SY merupakan teori revolusi pembelajaran. Hasil wawancara yang dilakukan peneliti di ruang tamu sekolah SMP Muhammadiyah 13 Wonosegoro:

"Yah memang harus di awali dengan senang dulu mas, jadi diharapkan bagi guru yang ingin masuk kelas hatinya dalam kondisi senang tidak boleh membawa masalah dalam kelas, yang akan menjadi suasana lingkungan belajar tidak menyenangkan mas, masih banyak ragamnya mas mulai dari merubah kondisi tempat duduk, mengajak anak belajar di alam terbuka dengan cara tadabur alam dan cerita hal-hal yang membangun semangat, anak bosan belajar di dalam kelas mas."

Lingkungan belajar yang kondusif karna akan mempengaruhi proses pembelajaran yang dijalankan bagi pendidik dan peserta didik, diawali dengan sikap guru yang tampil ceria dan semangat ketika bertatap muka denga peserta didik merupakan langkah awal yang baik, dilanjutkan kebutuhan yang diperlukan dalam kegiatan belajar mengajar seperti kondisi lingkungan belajar yang bersih dengan membangun kesadaran anak didik agar menjaga dirinya tetap bersih dan tertib dalam 
berseragam, memberi aturan yang jelas dan tegas, dengan mengodisikan lingkungan yang nyaman, relaks, aman, dan kondusif. Maka akan mempengaruhi mental siswa secara psikologis dalam menerima informasi dari guru, teman, dan lingkungan sekitar. lingkungan belajar akan mempengaruhi suasana hati yang berada di sekitarnya. Surat AlBaqorah ayat 25 memberikan kabar gembira terhadap peserta didik merupakan bagian kenyamanan dalam menebarkan energi positif hingga dapat menciptakan iklim keharmonian jiwa anak didik. Menurut Hamid (2013:118) lingkungan kelas mempengaruhi kemampuan siswa utuk fokus dan menyerap informasi. Bila suasana dan kondisi dalam kelas berantakan, kumuh, kotor, dan tidak menarik bagi siswa, maka peserta didik menganggap bahwa belajar itu tidak nyaman, melelahkan, dan kuno. Sebaliknya, bila lingkungan ditata dengan baik, bersih, sehat, dan nyaman, serta mampu mendukung pembelajaran, maka peserta didik memiliki pandangan bahwa belajar itu menyenangkan dan mengasyikkan.

\section{Menarik Minat}

Penerapan pembelajaran pada bapak ES merupakan teori pembelajaran aktif dengan metode ceramah. Hasil wawancara yang dilakukan peneliti di ruang tamu sekolah SMP Muhammadiyah 13 Wonosegoro:

"Strategi pembelajaran yang saya amalkan biasanya cerita kisahkisah Alim ulama dan biasanya saya berikan contoh juga orang yang berbuat baik kepada orang tua, teman, orang lain. Tidak lupa juga memberikan contoh perbuatan tidak sopan kepada orang tua, teman sebaya atau orang yang lebih tua dengan cara memceritakan kisah-kisah yang ada balasannya/azab. Biasanya anak senang sekali dengan model cerita gitu mas." 
Teknik yang dapat dipergunakan guru untuk meningkatkan konsentrasi siswa dan menarik minat dalam belajar, guru hendaknya memberikan alasan-alasan kepada peserta didik, mengapa harus belajar dengan sungguh-sungguh dan berusaha untuk berprestasi sebaik-baiknya dengan cara memberikan motivasi dan pencerahan yang terkait dengan matapelajaran dan strategi yang diterapkan. Guru perlu menjelaskan kepada peserta didik apa yang diharapkan dari siswa selama dan sesudah proses belajar berlangsung. Tentunya guru akan senang ketika anak didiknya memperhatikan, konsentrasi, dan antusias ketika kegiatan belajar mengajar sedang berlangsung, maka dari itu guru harus pandai memberikan sesuatu hal yang menarik minat anak didik, tentu dengan sesuatu yang berbeda dan tidak membosankan dengan gaya sajian pembelajaran yang menyenangkan dan sesuai psikologi anak didik yang seimbang.

\section{Menyajikan Materi yang Relevan}

Materi pelajaran menunjukan adanya hubungan dengan kebutuhan dan kondisi anak didik. Motivasi siswa akan terpelihara apabila anak didik menganggap apa yang dipelajari memenuhi kebutuhan pribadi, bermanfaat, atau sesuai dengan nilai yang dipegang. Trend pendidikan abad 21 berorientasi pengembangan potensi manusia, perkembangan zaman yang syarat dalam teknologi berdapak pada hal positif dan negatif, tinggal bagaimana manusia memanfaatkan teknologi tersebut, seperti kemudahan akses dalam mencari ilmu tentunya sudah banyak dari berbagai macam website dan blog. 
Begitu pula dengan hal negatif yang mudah diakses dalam situssitus yang mempengaruhi moral dan akidah putra-putri bangsa ini, berupa film yang tidak layak disaksikan oleh anak di bawah umur sehinggah orang tua dituntut lebih waspada pada pengunaan internet dan hand phone, era globalisasi ini. Menuntut sumber daya manusia agar selalu mengikuti perkembangan dunia agar tidak ketinggalan, dan ditindas oleh zaman. Begitu pula guru, memberikan materi pelajaran disesuaikan oleh kebutuhan peserta didik yang relavan dalam penyajian didasari perkembangan zaman, materi pelajaran tidak harus didapat melalui buku paket yang sudah disediakan sekolah akan tetapi bisa dikembangkan dengan mengakses internet, media televisi, dan media masa (koran/majalah). Mengembangkan potensi anak didik melalui inovasi. Guru dapat memberikan umpan balik kepada peserta didik sehinggah apa yang disampaikan guru anak didik dapat memahami kondisi saat ini dan yang telah lampau. Anak didik dapat memberikan argumen apa saja selama siswa mempunyai sumber/dasar yang dapat dipertanggung jawabkan.

\section{Melibatkan Emosi Positif dalam Pembelajaran}

Emosi positif sangat membantu pembelajaran karena perasaan dapat menentukan kualiatas dan kuantitas belajar peserta didik. Perasaan negatif bisa menghalangi proses belajar, sebaliknya perasaan positif dapat mempercepat proses. Belajar dengan penuh tekanan, menyakitkan dan suasana tidak nyaman, tidak dapat mengungguli hasil belajar menyenangkan, santai, dan menarik hati (Hamid, 2013:67). Peserta didik mendapat rangsangan menyenangkan dalam pembelajaran dari interaksi 
guru kepada siswa, akan menciptakan keaktifan dan kreatif secara mental dan fisik peserta didik. Pada saat seseorang tertawa atau tersenyum aliran darah akan berproses bergerak keseluruh anggota tubuh, yang membuatnya semakin aktif, otak menerima suplai darah yang memadai. Artinya dengan kenyamanan dan kesenangan yang dinikmati oleh anak didik itu, sangat membantu mereka mencapai keberhasilan belajarnya secara optimal.

Selain memberikan materi dengan baik. Guru pun harus bisa menjadi kawan dari siswa, dengan memberikan perhatian prilaku kebiasaan seperti menanyakan kegiatan sehari-hari yang dilakukan dirumah akan menciptakan kedekatan emosi guru dengan peserta didik dan mengetahui kecenderungan minat tiap anak didik. Cara ini mata hati guru dapat terlatih hingga memberikan perhatian penuh dan mampu memuaskan rasa keingintahuan siswa, guru jangan pernah membandingkan/pilih kasih terhadap siswa dalam menjalin komunikasi. Pastikan peserta didik merasakan guru dapat memberikan kasih sayang yang merata.

Adapun Sagala (2011:121) mengatakan dalam strategi pembelajaran edutainment pembelajaran ada pada proses pembelajaran yang menyenangkan, nyaman dan mengagumkan serta ada pada bagaimana hubungan antara guru dan murid dapat terjalin dengan pendekatan dedaktik metodik yang bernuansa pedagogis. Artinya interaksi antara guru dan murid tidak dijalin dengan komunikasi yang kaku tetapi harmonis seperti guru sangat luwes, akrab dan bersahabat sebagaimana teman sendiri. Dengan begitu siswa tidak merasa dibatasi, 
takut dan bisa berinteraksi dengan bebas dan menyenangkan. Strategi pembelajaran edutainment yang di terapkan di SMP Muhammadiyah 13 Wonosegoro merupakan hal yang baru, sehingga apapun hal yang baru dalam mengaplikasikan masih jauh dari kesempurnaan.

Hubungan dengan lingkungan atau yang populer kita sebut hablun mina Allah wa hablun minan naas. Pendidikan Agama Islam perlu betulbetul di terapkan ke dalam teknis pendidikan, baik dasar, menengah pertama maupun akhir. Baik secara formal maupun informal.

\section{Hambatan dalam Strategi Pembelajaran Edutainment pada PAI}

Tak ada gading yang tak retak, tak ada yang sempurna di dunia. Karena pemilik kesempurnaan hanya Allah SWT. Penerapan strategi pembelajaran edutainment yang dirancang sebaik mungkin agar siswa merasa nyaman, senang, aktif, dan antusias dalam pembelajaran tidak luput dari kekurangan dan hambatan. Jenis-jenis hambatan yang terdapat dalam penerapan strategi pembelajaran edutainment pada mata pelajaran PAI Hasil wawancara di SMP Muhammadiyah 13 Wonosegoro di ruang tamu sekolahan menurut bapak MLK mengemukakan:

"Kalau di luar kelas masih banyak resiko pembelajaran yang mana guru kurang memahami tentang edutainment dalam penerapannya, belum lagi guru Mapel PAI dapat mengefektifkan waktu dan pengkondisian anak ketika di luar kelas yang membutuhkan tenaga extra, hal yang menjadi perhatian khusus ketika anak keluar kelas memberi ruang gerak siswa merasakan bebas yang sulit terkontrol, terkadang apa yang diharapkan untuk lebih baik membutuhkan proses/memakan waktu yang panjang, walaupun begitu saya senang sekali dengan penerapan strategi pembelajaran edutainment yang insya Allah akan menaikan 
wacana dan prestasi Pendidikan Agama Islam kedepannya mas. Mestinya metode ini bisa digunakan oleh guru Mapel lainya, akan tetapi saya akan memberikan suport pada guru yang berani menggunakan metode yang kiranya anak didik menjadi lebih baik dan dapat memberikan prestasi untuk sekolahan. Saya ini kan masih baru menjadi kepala sekolah, ya baru beberapa bulan kok mas, tepatnya pada bulan november 2013 kemarin, jadi saya masih punya PR untuk memperbaikin internal sekolah."

Wiliam Arthur Ward dalam bukunya Ahmad (2005:3) bahwa guru yang biasa adalah memberi tahu, guru yang baik adalah menjelaskan, guru yang superior adalah menunjukkan dan guru yang berjiwa besar adalah menginspirasi. Minimnya pengetahuan sumber daya manusia tidak dapat dipungkiri menjadi permasalahan untuk mengembangkan strategi pembelajaran edutainment dalam menselaraskan visi, misi SMP Muahammadiyah 13 Wonosegoro. Guru yang kurang proaktif mengembangkan strategi pembelajaran edutainment menjadi penghambat berjalannya metode yang terkait dengan edutainment. Hal ini menjadikan strategi pembelajar yang dikonsep begitu baik tampak seperti biasa. Sebab sang eksekutor yang kurang memahami secara keseluruhan sesuai dengan pendapat bapak MLK guru yang hanya setengah-tengah memahami baik berupa persiapan bahan dan rencana proses pembelajaran yang lama, anak kecenderungan bermain, berdampak pada hasil yang kurang memuaskan dari tujuan pembelajaran. Waktu yang terbatas menjadikan alasan pokok bagi pendidik dalam menjalankan strategi tersebut, belum lagi sarana dan prasarana yang terbatas menghambat dalam menerapkan. Beban yang baru memacu guru PAI untuk lebih baik dalam menjalankan hambatan-hambatan. 


\section{Teknik Mengatasi Hambatan}

Hal yang baru tidak akan lepas dari segala hambatan artinya masih ada hal yang ganjil. Guru PAI yang sedang menerapkan sesuatu yang baru akan menghadapi masalah yang baru diantaranya: sumber daya manusia yaitu guru, peserta didik, bahan pembelajaran, waktu pembelajaran, minimnya alat/media pembelajaran yang terbatas serta situasi dan kondisi lingkungan yang kurang mendukung dalam kegiatan pembelajaran. Teknik mengatasi hambatan yang ditemukan untuk menerapkan strategi pembelajaran edutainment pada mata pelajaran PAI. Berdasarkan hasil wawancara di SMP Muhammadiyah 13 Wonosegoro di ruang tamu sekolahan menurut bapak MLK:

"Hambatan hal yang biasa dalam kehidupan, tinggal bagaimana kita menyikapinya dan menghadapinya, sebagai mana tentang pembuatan RPP dengan metode pembelajaran yang baru dengan merubah bahan dan strateginya setelah itu baru disesuaikan dengan metode apa yang digunakannya, dengan pengaturan waktu yang sangat minim saya sudah koordinasikan dengan Waka Kurikulum tapi masih belum ada jawaban, akhirnya saya membuat program madrasah semacam extrakulikuler yang isinya tentang program PAI, masalah alat yang belum lengkap sekolah selalu mengupayakan apa saja yang dibutuhkan oleh guru PAI, anak didik yang belajar di luar kelas saya telah bicarakan kepada staf keamanan/satpam untuk mendampingi guru agama ketika belajar diluar kelas."

Guru adalah pelaku pembelajaran, sehingga dalam hal ini merupakan faktor terpenting, ditangan gurulah sebenarnya letak keberhasilan pembelajaran (Hamruni, 2011:11). Hambatan pertama yang dihadapi guru yaitu guru yang kurang proaktif ketika ada perubahan strategi dan metode pembelajaran dari pihak sekolah, teori yang 
mengatakan sukses atau tidaknya pembelajaran ditangan guru merupakan suatu hal yang diutarakan bapak kepala sekolah dalam pertemuan rutin guru PAI, dengan cara begitu bapak MLK memberikan bimbingan dan pengarahan bagi guru yang kurang mendalami pemahaman edutaiment, dukungan bapak kepala sekolah untuk mengaktualisasikan visi, misi sekolah dengan strategi pembelajaran edutainment mata pelajaran PAI merupakan harapan untuk meningkatkan citra sekolahan yang diamanahi bagi dirinya. Guru yang kurang memahami makna edutainment ditekankan agar tidak bosan bertanya ataupun mencari informasi yang mendalam.

Hambatan yang kedua adalah faktor dari Peserta didik merupakan objek dalam sebuah pembelajaran. Dimana potensi yang dimiliki pesrta didik yang harus dikembangkan oleh gurunya dengan berbagai pendekatan baik berupa keteladanan, pembiasaan, bermain peran dan lain-lain.

\section{Dukungan Kepala Sekolah, Guru, dan Siswa dalam Menghadapi Hambatan Strategi Pembelajaran Edutainment pada PAI}

Manusia adalah mahluk sosial yang tidak mungkin hidup sendiri, membutuhkan seseorang dalam segala hal menjalani kehidupan, dilahirkan di dunia dengan keadaan menangis yang menunjukan ketidakberdayaannya, dari lahir hingga saat ini. Tak ada satupun manusia yang mampu hidup tanpa orang lain. Begitu pula dengan kesuksesan pembelajaran tidak berarti ketika tidak ada dukungan dari bapak kepala sekolah, guru dan peserta didik. Ketiga komponen inilah yang 
mempercepat keberhasilan strategi pembelajaran. Tanpa dukungan kepala sekolah menjalani strategi pembelajaran akan banyak kendala dan hambatan, begitu juga tanpa ada guru yang membantu menjalankan strategi pembelajaran edutainment akan terasa berat, tanpa ada siswa yang mendukung strategi pembelajaran edutainment tanpa arah tujuan. Hasil wawancara di SMP Muhammadiyah 13 Wonosegoro di ruang tamu sekolahan. Dukungan Kepala Sekolah, guru dan siswa dalam menghadapi hambatan strategi pembelajaran edutainment pada PAI bapak MLK berpendapat:

"Dukungan kepala sekolah tentunya sangat optimal mas, saya yang menganjurkan hal yang baru ini, jadi saya bukan hanya perintah saja akan tetapi mempraktikannya bagaimana hambatan dan kesulitannya tentu saya sangat faham betul mas, karna saya juga terjun langsung dalam kegiatan pembelajaran edutainment, bahkan saya pesan kepada guru agama apabila ada kesulitan yang kiranya membutuhkan tenaga untuk ngomong sama guru yang tidak ada kegiatan di kelas ataupun kepada staf keamanan dan kebersihan, untuk membantu. Jadi di sini saya menekankan kekompakan mas dan kekeluargaan. Siswapun selalu menjalin komunikasi dengan saya baik apabila ada kendala/permasalahan dalam pembelajaran bisa sms saya langsung mas."

Dukungan yang telah diberikan kepala sekolah sangatlah penting dalam lingkungan sekolah, sehingga memudahkan dan melancarkan program strategi pembelajaran edutaiment, dari berbagai macam kebijakan kepala sekolah memberikan asupan energi positif bagi pelaksana program strategi pembelajaran, yang awalnya tampak berat/sulit dilaksanakan menjadi ringan dengan dukungan para guru dan siswa. 


\section{Simpulan}

Strategi edutainment pada mata pelajaran Pendidikan Agama Islam (PAI) di SMP Muhammadiyah 13 Wonosegoro Boyolali. Strategi pembelajaran bagi guru merupakan rencana tindakan/rangkaian kegiatan dalam menggunakan dan memanfaatkan metode dan sumber belajar. Strategi ini disusun untuk mencapai tujuan tertentu yang ditetapkan oleh guru. Penerapan strategi pembelajaran bagi guru merupakan hal penting untuk mencapai prestasi belajar. Penerapan strategi pembelajaran harus memahami psikologi peserta didik agar dapat menggerakkan motivasi, inovasi, kreativitas siswa dalam belajar. Oleh kerena itu, sentuhan nilai seni yang dimiliki oleh guru dalam melaksanakan proses pembelajaran di kelas tidak sekadar transfer of knowledge tetapi juga transfer of value.

Suasana belajar yang menyenangkan dapat dirasakan oleh peserta didik dalam mencapai prestasi belajar. Strategi pembelajaran edutainment diharapkan dapat mencetak lulusan yang tidak hanya dalam nilai (angka) yang baik, namun memiliki kecerdasan kognitif, emosional, dan kecerdasan spiritual. Penerapan strategi pembelajaran edutainment yang memadukan sistem edukasi dan entertainment dalam pendidikan dapat memberikan proses pendidikan yang dapat sangat menarik sekaligus menghibur peserta didik. Guru dan peserta didik merasa senang, nyaman, tidak menimbulkan kebosanan dalam kegiatan pembelajaran di kelas untuk mencapai tujuan pembelajaran yang ditetapkan. Proses pendidikan dengan pendekatan edutainment melalui permainan (game), humor, bermain peran (role play), dan demonstrasi dan cara-cara lain yang dapat dikuasai oleh guru dan siswa. 
Hambatan strategi pembelajaran Edutainment pada mata pelajaran PAI di SMP Muhammadiyah 13 Wonosegoro tahun 2014 antara lain: sumber daya manusia dalam menjalankan strategi pembelajaran Edutainment, peserta didik cenderung bermain hingga melupakan esensi pembelajaran, bahan pembejaran, waktu pembelajaran yang minim, sarana dan prasana yang terbatas, lingkungan belajar yang kurang mendukung dalam penerapan strategi pembelajaran edutainment.

Cara mengatasi hambatan strategi pembelajaran edutainment pada mata pelajaran PAI di SMP Muhammadiyah 13 Wonosegoro tahun 2014 di antaranya dari segi sumber daya manusia dengan pembinaan yang dilakukan kepala sekolah, mengikuti workshop, seminar studi banding, siswa cenderung bermainnya dengan memberikan motivasi dan manfaat belajar yang akan dilaksanakan, bahan pembelajaran yang belum ada acuannya dapat mencontoh bahan pembelajaran kurikulum 2013, waktu yang minim dapat dimaksimalkan dengan persiapan yang matang dan manajemen waktu. Sarana dan prasarana terbatas guru dapat meningkatkan kreatifitas dalam mesinergikan metode dengan materi pelajaran yang akan diajarkan, lingkungan belajar yang kurang mendukung dapat dengan melakukan pembelajaran di luar kelas, baik di alam terbuka atau di mushola sekolah.

\section{Daftar Pustaka}

Nurcholis, A. (2005). Pendidikan Agama Islam berwawasan Multikultural. Jakarta: Gramedia

Effendi, A. (2005). Revolusi Kecerdasan Abad 21 Kritik MI, EI, SQ, \& Succesful Intelligence atas IQ. Bandung: Alfabeta. 
Hamruni. (2009). Edutainment dalam Pendidikan Islam \& Teori-Teori Pembelajaran Quantum. Yogyakarta: Fakultas Tarbiyah UIN Sunan Kalijaga.

Hamruni. (2011). Strategi Pembelajaran, Yogyakarta: Insan Madani.

Kadarsih. (2012). Power Full in Educating, Yogyakarta: Araska Pinang Merah.

Markowitz, Karen \& Jansen, E. (2002). Otak Sejuta Gigabite.

Hamid, M. S. (2013). Metode Edutainment (Belajar Pembelajaran), Yogyakarta: Diva Press

Moeleong, J. L. (2010). Metodologi Penelitian Kualitatif. Bandung: Remaja Rosdakarya

Sagala, S. (2000). Administrasi Pendidikan Kontemporer. Bandung: PT Rosda Karya.

Sutrisno. (2005). Manajemen Keuangan Teori Konsep dan Aplikasi. Yogyakarta: Ekonosia. 
Mudarrisa, Jurnal Kajian Pendidikan Islam, Vol. 8, No. 1, Juni 2016: 117-144 